\title{
The Category of Number in Different Language Systems
}

\author{
Ayten Mahammad Bayramova \\ Azerbaijan University of Languages
}

\begin{abstract}
Philosophical or logical category of number is based on the existence of quantitative characteristics of things and events of the reality. A human being first comprehended the number of things and objects and then tried to express them by means of languages. Gradually there appeared the existence of more than one things and there emerged the necessity of expressing them. In Turkic languages, including Azerbaijani, the abundance of things began to be expressed by the numeral three, then it reached forty, which was the maximal limit. It found its expression in fairy-tales and eposes, as well as in proverbs. For instance: Atalar üçəcən deyiblər (Our forefathers counted up to theree or allowed do something only thrice); Üç gün, üç gecə yol getdilər (They walked three days and nights); Qırx gün möhlət vermək(They granted him a delay for forty days); Qırx gün, qırx gecə döyüşmək (They fought for forty days and nights); qırx qapını açmaq (to open forty doors); divin canını qırxıncı otaqda tapmaq (to find the vigour (life) of the giant in the fortieth room), etc. All this shows that the expression of the category of number in language has undergone a long historical process.
\end{abstract}

Key words: quantity, number, category of number, plurality,pairedness, multitude

\section{INTRODUCTION}

The logical category of number emerged at the stage of the process of cognition when a man was already able to approach the things and events from the point of view of their quantitave characteristics, and this category found its expression in language in the form of the grammatical category of number.

When men began to approach things and articles from the point of their number, they understood plurality or singularity as a qualitative feature of things and events. Quantity was understood as one of the features (colour, form, measure, incountability, etc.) which characterized the plurality of things and articles. It is not accidental in the majority of the present languages, for example, in English, that the countability and uncountability of things are taken into consideration. It should be also noted that in many languages the category of plurality emerged long before the meaning of abstract number.

In more ancient periods in the development of a number of languages there were lexical or morfolocical indicators which expressed plurality. If the quantity was expressed within the frames of a category, it meant that the bearer of that language was able to abstract this notion in his thinking and to understand the essence of the number.

In the initial stage men understood the quantity of things as the quality, while later, after comprehending the essence of quantity, they began to distinguish this feature of things and objects from the quality. According to V. Z. Panfilov, number is an abstract category peculiar to the generalised thinking. The expression of concrete plurality of things cannot be regarded as the initial stage in the birth of this category [Panfilov 1977, p.168]. 
The main issue of the category of number is to distinguish the single from the plural and to create the means of their expression. Nevertheless, determination of the means expressing different forms of the meaning of quantity has become one of the complicated problems. In reality it is not only singularity and plurality that become evident. People have revealed binarity, (un) countability, (in) definiteness, (im) measurability, singularity, plurality, infinity, (in) seperability and other features. All this does not find its expression only by means of the grammatical category of number. Each language has different constituents in its functionalsemantic field which creates opportunities for expressing different specific features of number in language. Nevertheless, there emerge identical and non-identical features in the means of expression, as well as in the discovery of different forms of number.

\section{METHODOLOGY}

Before approaching the large numbers of things not as the total number of these separate objects, the ancient man comprehended them as a multitude. Here the attention was focused not on the fact that these things were comprehended as the total number of things but on their existence in the form of a multitude. In those days perhaps the multitude was not regarded as the number of things, but as their quality, and the multitudes consisting of different objects were comprehended as their different features or signs. The multitude of things was expressed differently in different languages which is connected with the relation of the language and culture. Each language reflects the attitude of its bearers to objects and events. The cultural context exerts an impact on the reflection of certain categories in the language, including the category of number. In the ancient written sources of the Slavic languages the plural of the nouns has been expressed with special plural nouns. These nouns also were used in singular from grammatical point of view. There is such a view that to express the plurality of nouns the word-forming suffixes were used. It may be regarded as the expression of plurality by lexical means. In the later stage of development of Slavic languages the indicators of plurality began to function as grammatical suffixes of plurality. In a number of languages, (in the Slavic languages as well) there are many lexical units which express plurality.

In Azerbaijani the notion of singularity in the category of number is nill, i.e. it has no grammatical indicators. It is obtained by the juxstaposition of the word-form of the plural ending of singular with the word-form which has a plural ending. Singularity has no ending, while plurality is formed by adding a number of suffixes in Azerbaijani. The plurality forming suffixes include - lar, (-lər), -lıq (-lik, -luq, -lük ), -lı (-li, -lu, - lü), -q (-k), -lq (-ik,- uq. -ük), - lz (iz, -uz.- üz), -gil.

As quantity is a relative notion, the suffixes of the paradigm of person, as well as some wordforming suffixes, are added to the word for expressing the plurality of the number. Inclusion of these suffixes into the group of the suffixes of the category of number creates a different feature in the opposition of paradigms.

While reviewing the expression of plurality in Turkic languages Zh. Garibova makes such an inference that "plurality in the early periods of development in ancient Turkic languages was connected with a certain indicator. According to her, "It could have existed in the pre-Altaic or pre-Uralic periods. In the later periods of development of the language when different notions expressing plurality began to be comprehended in the meaning of common quantity, the borders existing among their means of expression gradually disappeared" [Garibova 1994, p.20]. 
When a cardinal number expressing plurality is follwed by a noun, the sign expressing plurality is used on the second side, which is an indication of the fact that the logical rule inherent to the category of number in Azerbaijani differs from other languages. For instance, the notion of beş kitab is expressed as five books in English, as pənc ketabha in Persia. In Russian plurality of the second side is expressed in different ways, including the way by means of different suffixes from grammatical point of view: пяти баранов, десяти тетрадей, десяти домов, двое друзей and so on.

Another feature of word-changing differing it from the word-formation is the serious parallelism between the core words and their derivatives. Obviously, in English all the plural forms of nouns are formed from their singular forms, or on the contrary, that is, all the plural forms of nouns derive from their singular forms. In English in most cases the plural form of nouns consist consists of two pairs - from a singular noun (a hat - şlyapa) and a plural noun derived from singular noun (hats -şlyapalar). When one of them is known to the speaker, he may construct the second one himself. The chain of each of such a form is called a paradigmatic set of a paradigm and each part in this chain is called inflected form or inflection.

The characteristic contradiction of the meaning for the category of number is tha ability of the singular to denote plural objects (Eng. - army, tribe; Russian -армия, племя; Azerbaijaniordu, qəbilə, tayfa, xalq, etc.) and the ability of the plural form to denote the single object(Eng: glasses, shorts; Russian - очки, шорты, etc.). Sometimes the same object has both singular and plural forms (Eng: - moustache-moustache, rein-reins; Russian: -сеть-сети, штат-штаты, etc.). Complications in defining the plurality or singularity of the words, absence of two words in the opposition of the number reveals contradictions in the linguistic interpretation of the category of number.

According to G. N. Vorontsova, the singularia tantum and pluralia tantum nouns are deprived of the category of number, and some nouns are far from the words having quantitative meanings. The notions of separation, division, counting do not create an association [Vorontsova 1960, 108-109]. In a number of words the borders of the number is not distinct, for instance, scissors, hustings, gallows, etc. Such words are used in combination with a part of. It is also observed that some plural forms are compliant with the singular forms. The following word combinations cause interest from this point of view: 20 pound, a few ton, 40 head of poultry, 20 head of game, a couple of year, a fleet of 20 sail.

In this case a word which does not express plurality and names a new object, becomes a unit expressing plurality in certain contexts. It is possible to relate them to the words denoting measure, weight and number. In Azerbaijani in word combinations like gül almaq (to buy flowers), çiçək almaq(to buy flowers), kartof almaq(to buy potatoes), buğda almaq(to buy wheats), qənd almaq (to buy sugar), the things which are bought and are single in form do not express singularity. Here only intention of the purchase is mentioned. Concreteness emerges in the process of the purchase. In this process the quantity becomes specified by using different words. For instance: Üç dənə gül alıram (I am buying three flowers); Bir kilo qənd alıram (I am buying a kiolgram of sugar); Beş kilo buğda almaq istəyirəm (I want to buy five kilograms of wheats); Bir kisə kartof götürəcəyəm (I shall take a sack of potatoes). Some words within the word combination play the role of a specific unchangeable form. They express the meaning of wheight, measure, distance. This is characteristic for English, too. For instance: 40 head of poultry, 20 head of game, a couple of year, a fleet of 20 sail. 


\section{ANALYSIS}

In English and Russian there are not less cases when one and the same word expresses both singularity and plurality of the objects and events. It depends on the comprehension of the object, or the group of objects. On the other hand, there are also not less cases when the same object and event is expressed with a word having a different quantity-biased meaning. For instance, in English brain-brains, nerve-nerves, moustache-moustaches, ear-ears, eye-eyes ( the words ear, eye express the meaning of both eyes and ears), in Russian: сеть -сети, дверь двери, штат - штаты, etc. Identical cases are also encountered in Azerbaijani. In some cases the word may have the meaning of plurality, though the singular form is used. For example: Gözümün içinə düz bax! (Look directly into my eyes!); Qulağını aç və sözlərimi yaxșı eşit! (Open your ears and hear my words well!); Böyrəyi xəstə deyil ki? (Has he got a kidney disease?) In these sentences not one of the objects having singular or plural forms is meant. When we say "Gözümün içinə düz bax!" (Look directly into my eyes!), one does not mean one of the eyes (right or left), both of the eyes are meant. It is interesting that in some languages, for instance, in Hungarian, the pair parts of human body (hands, eyes, etc.) are taken as a whole and used in singular. To express a hand, a foot, an eye, the word half is used. 0. Yespersen calls this kind of words "composite objects" and classifies them into five sense groups: 1) clothes gloves, sleeves; 2) equipment- arms, fetters, compasses; 3) building, construction, office archives, barracks; 4) parts of human body - brains, lights (lungs); 5) activity, ceremony, games - nuptials, obsequies, dominoes [Jesperson 2002, p.234-246].

D. I. Arbitsky calls these things "complicated articles" and classifies them into eight groups: 1) names of the parties of bodies of human beings and animals - руки, ноги, лапы ( hands, feet, paws); 2) clothes and articles of ornament - туфли, жемчуга (shoes, pearls); 3) names of tools, equipment and pastahs - цепи, вожижи (chains, reins); 40 means of transportation - сани, (sledge, sledge drawn by dogs or reindeer); 5) names of closed-type spaces- rooms, chambers (комнаты, покои); 6) names of texts and publications - couplets, notes (куплеты, ноты); 7) names of knowledge, information, idea - foundations, information, ideas (основы, виды, помыслы) [Arbatsky 1972, p.93-94].

It is necessary to note that in a number of languages with different structures the category of number consists of a three-stepped opposition. In Semitic languages the category of number has special indicators which express the notion of pairedness. For instance, in the Accadian language: -a, -an, in Arabic: -ani etc.function as formants which express pairedness. The form of nouns expressing pairedness exist in Koryak, Eskimoan, Tibetan , in some Papuan langages, too. For instance, in the Accadian language -a, -an, in Ivrit -aüm, in Arabic -ani and others function as formants expressing pairedness. But the expression of pairedness in these languages is not like that in Turkic languages where special pair formants did not initially exist. Not only indicator $-\mathrm{z}$, but some other indicators like /-n, $-\mathrm{t},-\mathrm{q} /$ have taken part in the formation of pair nouns, for instance, qanad (wing), yanaq (cheek), çiyin ( shoulder). On the other hand, these indicators join the unpaired nouns expressing not their pairedness, but their plurality. According to some scholars, the formants, which were considered to be the indicators of plurality, originally were the indicators of collectiveness. Very probably, the adherents of this idea have based on the hypothesis that in all the languages the notion of topluluq has emerged before the birth of the notion of plurality. Such facts evidence that the shade of the notion of quantity has served the basis for the birth of its other shades from the point of view of the content and form. Primacy is inherent only to the form. In language the notion of singularity is used in order to distinguish it from the plurality of identical units. It also finds its expression in quantity. 
In Azerbaijani there are structural-semantic units, which express singularity and plurality, as well as definiteness and indefiniteness. The singular nouns form the nuclear in the functionalsemantic in singularity micro-field. They bear information on the singularitry of the object: "Sonra yeşikdən çıxartdığı qızıl qol saatını stolun üstünə qoydu" (Elçin). - Then he put on the table the gold watch which he took out from the box; "O, sağ əlində tapança tutmuşdu" (Elçin).He had a pistol in his right hand; "Qutuda qizıl medalyon var idi" (Elçin).-There was a gold locket in the box.

The singularity of the subject finds its expression in the singular of the personal pronouns, in the suffixes denoting singularity of the person, in the singular of the reflexive pronouns, in the names of objects. For instance: "Mən səndən ayırlmazdım, zülm ilə ayırdılar" (from the song) - I would have not left you, we were separated tyranically; "O atdı özünü varın qoynuna" (M.Ismayll) - She threw herseld into the bosom of the wealth and property; "sallana-sallana gedən Salatın, çox belə sallanma göz dəyər sənə" (Aşıq ələsgər) - (Salatin, do not coquet, if you walk like that, or evil eyes will be cast on you), etc. It is necessary to note that the discovery of singularity by the said means very often remains in the position of background in the content of the transferred information, i.e. in the avove-demonstrated examples the main purpose or the transferred main information has not been built on the expression of quantity. The information in them about quantity is factual.

In Azerbaijani the zero ended variant is characteristic for the morphological expression of singularity, i.e. the word does not accept any ending for the singularity of the number. Personal endings and pronouns remain in isolation at the morphological level. In fact, they are used to denote the subject and object of the action, event or phenomenon. In special cases this subject or object is single. The noted facts are not inherent only to Azerbaijani, it is evident identically in the majority of languages. Therefore, it is necessary to look for the specific features in the expression of number in the first place in quantity indicators connected with multitude and pairednes.

Using of singularity in some languages and plurality in others for the expressing of pairedness may be considered a specific feature for the expression of quantity in language. Here the expression of plurality is mainly connected with the subject itself. In some languages the semantics of pairedness or duelty is revealed in naming the articles. For instance, in Russian the word щипцы (tongs) is the name of a tool having different forms and types. This tool consists of two identical parts. That is, the two parts used in making that tool are similar or completely identical. The difference between them is revealed in connection with symmetry. Two identical parts join and make a tool. Here the article is one, but there is a pairedness, a duelty of its parts. It gives rise to the issue of a double number. The Russian word ножницы (scissors) is also the name of a tool consisting of a pair of parts. The existence of two parts (knives) was the ground of the formation of this name. In the Bulgarian language this word has both singular ножница and plural ножницы forms. This tool in Azerbaijani is called qayç. The name does not bear any information about the pairedness in it. It has both singular (qayçı) and plural (qayçlar) forms.

\section{DISCUSSIONS}

Double number category was inherent to many languages, including the Indo-European and the Semitic languages. In the majority of the Indo-European languages the double number has disappeared. But certain traces of this category in them are still being preserved. In Modern Russian the traces of the double number are preserved in the names of a number of articles as 
щипцы, ножницы, шаровары, очки, глаза, рукава, плечи, колени, etc. But when these articles are subjected to analysis from the point of view of their number, it is possible to distinguish two types of them. Some of these articles have been named due to the identity, similarity of their two parts. In another case the coexistence of two same articles has been fore fronted. Some parts of the human body consist of identical pairs, for instance, eyes, cheeks, lips, ears, kidneys, knees, shoulders, etc. In this case the object of the analysis becomes not the existence of two identical articles of the same thing, but the paired existence of the same thing. Some languages use plural form of nouns for expressing this pairedness, taking the paired articles together. For instance:

1. Hərənin iki gözü var;

2. Birini çıxarmayıbsa

3. Insan, daş, ya güllə (R.Rza)

4. Each one has two eyes;

5. If one of them has not been blinded

6. By man, stone or bullet.

Some languages differentiate the paired articles. They use both singular and plural forms. In Azerbaijani the expressions gözlərimin qarası ( the dark circle surrounding the apples of my eyes) and gözümün qarası (the dark circle surronding the apple of my eye) are used: Sən gözümün ağısan, ilk məhəbbət qarası (N. Kəsəmənli) -You are the white of my eye, my first love is the dark circle surronding its apple. It's natural that the poet does not take into consideration "the white" of one eye only. In the word combination gözümün ağı the number is shifted to the background. The pairedness of the eye is of no significance for the expression. In it the main thing is that the existence of the gözün ağı (the white of the eye) as well as its qarası (apple) are important for the eye to see.It is impossible to see if one of them is absent. This feature is characteristic for the other words having the same format: Olim əllərinin lap yanındadır, toxunsa, biz indi üzr istıyərik (N.Həsənzadə). - My hand is very close to yours, if it touches yours, we are to ask pardon from each other.

As it is seen, there is no unanimity in the definition of the paired words as a notion. In this case the pairedness and doubling of the articles are based upon. In Russian the terms парные предметы ( paired objects), двойственное число (dual number) are used. It is also necessary to note that the use of the plural form does not convey information on the pairedness or duality of the object.

In the process of comprehending the number of things, objects and events it is measured not only by exact mathematical calculations, but also by approximate subjective forms [Galich 2002, p.24]. If in science the exact measure of number, in real life the expression of the number is possible in different forms. In such cases the estimation of the quantity, its implicit or explicit, relevant or irrelevant expression depend on subjective approaches and ethnoculturological factors [Mechkovskaya, p. 230].

The main factor which conditions the relation of the culture and language is the man, the bearer of the language, the man who is able to think. In different nations the road leading from the real world to the notions and from there to the verbal expression of the idea is different. The lives, geographies, histories, daily lives of the nations are identical. Accordingly, the development of their sicial consciouness is different as well. The consciouness of a man, his attitude to ongoing processes and events are formed and develop under the influence of both collective and individual factors of comprehension. Therefore, language reflects the reality concerning its relation to the real life and to thinking. The national world picture is prior to the 
linguistic picture. Nevertheless, the language picture formed in the cognition influences both the culture and the manner of thinking. Language makes a man see the material world in a certain way. According to its features one culture is opposed to another culture. Culture is comprehended in the process of such confrontation. At the same time the semiotics of one culture becomes the property of another culture [Ryabtseva 2000, p.36].

\section{CONCLUSION}

The specific features in the expression of number, as it was noted, are evident mostly in plurality and pairedness. But these two distinguishing features do not cover all the idiosyncrasies of the expression of number in language.

There are words in all the languages connected with certain historical events, beliefs, customs and traditions. Spesific features are discovered in the quanitative characteristics of these words. For instance, in Azerbaijani the use of plural endings in the words yeddilər (the sevens), qirxlar (the forties), iyirmi altılar (the twenty-sixs), etc., is connected with specific reasons. In the Indo-European languages the names of many liquids may be used in singular and in plural. Here the plural endings seem to be word-forming endings rather than word-changing ones. In the Indi-European languages certain nouns differ in number, in other language families, for instance, in Paleoasian Samoa and Hindu languages, all the nouns denoting liquids change in number. If in the context there are words which denote the number, for instance, some (bir az, bir qədər), many (çox, çoxlu) and numerals (modal words, adverbs of degree etc.), the implicature encontered in this context is called quality imlicature.

Thus, existence of diversity in the expression of number in languages belonging to different language families finds its confirmation. The study reveales that the primary feature for the number in the language is the presence of singularity and plurality. In the majority of languages grammatical category of number finds its expression in singularity and plurality. However, in languages belonging to differen language families specific features are discovered while expressing pairedness and plurality.

\section{References}

1. Arbatsky, D.L. (1972).The plural form of hyperbolic plane. \#5, pp.91-96.The Russian language at school: Moscow Publishing House.

2. Chlenokova, A.A. (2007).Expression of different types of quantity in the language (on the material of the German language).pp.229-234.Vestnik: Sam. SU.

3. Galich, G.G. (2011).Cognitive strategies and language structures.p.232. Omsk: OMSU Publishing House.

4. Garibova, Zh. (1994).The ways of expression of the category of number in the Azerbaijani language. Ph.D dissertation. Baku.

5. Galich, G.G. (2002).Cognitive category of number and its realization in modern German language. p.208. Omsk: OMSU Publishing House.

6. Jesperson,0.(2002).Philosophy ofGrammar.p.408.Moscow:URSS.

7. Mechkovskaya, N.B. (2005). Gradual-numerical semantics in grammar, lexis and phraseology. Level diversity and interlevel correlation. Logical language analysis.pp.448-465. Moscow: Indrik.

8. Panfilov, V.Z. (1977). Philosophical problems of Linguistics. p.169. Moscow: Science.

9. Ryabtseva, N.K. (2000). Size and quantity in the world language image. Moscow: Foreign Language Literature Publishing House.

10. Vorontsova, G.N. (1960).The study of the English language Grammar.p.400.Moscow: Foreign Language Literature Publishing House. 
11. Yermakova, O.P. (1986). Transformation of quality into quantity (about the nature of intensifications) Logical language analysis. Quantitative language analysis. p.272-279. Moscow: Indrik. 